International Journal of Scientific Research and Management (IJSRM)

||Volume||06||Issue ||06||Pages||M-2018-44-58||2018||

Website: www.ijsrm.in ISSN (e): 2321-3418

Index Copernicus value (2015): 57.47, (2016):93.67, DOI: 10.18535/ijsrm/v6i5.m02

\title{
Population Growth and Primary School Enrollment in Yola-North, Adamawa-Nigeria
}

\author{
Emmanuel Torsen ${ }^{1 \dagger}$ and Peace Oaya ${ }^{2}$ \\ ${ }^{1,2}$ Department of Statistics and Operations Research, Modibbo Adama University of Technology Yola.
}

\begin{abstract}
:
This work is centrally focused on population growth and how it affect the enrollment of school age children (6-11 years age group). The population of $2006(199,674)$ was used as the base year to project the 2011 (234,329), $2016(274,972)$ and $2021(322,688)$ populations using the exponential growth model. Enrollment ratio was obtained by relating the total population of a particular level to the population that were enrolled at that particular level base on sex structure, the Gross Enrollment Ratio (GER) for male pupils from 2006 and 2011 was $70.21581 \%$ and $70.21696 \%$ which implies that $29.784 \%$ and $29.78304 \%$ of the male school age children are yet to be enrolled in schools, with a slight increase from 2006 to 2011. For 2016 and 2021, the GER is $70.2160 \%$ and $70.21696 \%$, that is, $29.784 \%$ and $29.7822 \%$ of the male school age children will not be enrolled in schools with a slight increase from 2016 to 2021. The GER for female pupils from 2006 and 2011 was $74.03832 \%$ and $74.03432 \%$ which implies that $25.9618 \%$ and $25.96568 \%$ of the female school age children are yet to be enrolled in schools, 2016 to 2021 is $74.0347 \%$ and $74.0374 \%$ meaning that $25.96168 \%$ and $25.9626 \%$ of the female school age children will not be enrolled in schools by 2016 to 2021. The Sprague multipliers coefficient (SMC) table was applied to break down the five (5) years age group in to sex structures, in which the total age population at primary school (6-11) years as of 2006 base on sex structure was 14,689 and 13,258 for male and female respectively, for 2011 was 17,239 and 21,427 for male and female respectively. This paper has shown that, while the population of Yola-North LGA is rapidly growing, the enrollment of school age children is also increasing but very slowly.
\end{abstract}

Key Words: Enrollment Ratio, Exponential Growth, Population Growth, Sprague multipliers

\section{Introduction}

Population growth at both national and state levels represents a fundamental indicator for national decision makers. As population increases, it is expected that children of school age and school enrollment increases. In Nigeria, Primary school education is universal and compulsory for every child of school age 6-11 years old. And it is empowered by the Federal Republic of Nigeria, it is very important therefore to investigate the number of children enrolled into primary schools as this could be important for achieving Universal Basic Education which is one of the target of the eight millennium development goals, at the same time build a solid foundation for economic growth. Globally, the process of mass education in most countries has increased tremendously (Mundenge, 1993, Saint, 1992 and Thian, 1991). Sawyer (1995) observed spectacular increase in the adult and primary enrollment rates throughout the continent of Africa.

Amutabli and Oketch (2003) cited that benefits of education remain enormous and unquantifiable. Education brings about sound knowledge, well-informed habits, sound ideas, skills and enhancement of positive attitudes. It is therefore essential, for it is still regarded as an important bridge of social, economic and political mobility. Record has it that, one hundred and eighty nine (189) countries so far 
have embraced the eight Millennium Development Goals (MDGs) aimed at eradicating poverty and improving the welfare of their people by 2015. Another on the list is "Achieving Universal Primary Education by the 2015, which implies that children all over the globe boys and girls alike would be able to complete a full course of primary schooling (World Bank Review, 1995). The question of how well has Nigeria with regards to MDGs is beyond the scope of this paper. Nigeria under the regime of Olusegun Obasanjo initiated the Universal Primary Education in 2001 by launching the Universal Basic Education (UBE). It was backed legally by UBE Act of 2004. This agreement is aimed at providing basic education for 9 years. The first six years of Primary and 3 years of Junior Secondary School, which should be free and compulsory.

Population growth and education development are closely inter-related. Population growth leads to an increase in number of persons to whom educational facilities have to be provided. On the other hand, educational development affects population trends through promotion of increased acceptance of family planning measures by the adults and delay in age of marriage. Universal Primary Education, that is, enrollment of all 6-11 years old children in primary school is the long term goal of the government. Primary education has also expanded has also expanded rapidly as a result of population growth and efforts of the government to provide access to primary education and also due to increased demand of the public for this level of education. The education for all plan of action (2005) has set target of attaining universal primary education by $2015 \mathrm{AD}$.

The World Bank survey reports that with the emergent population explosion rate of children between the age brackets of 6-11 years who are of primary school age that increase to 129 million in 1990, will increase to 162 million by the year 2015. Out of this number, how many would have being particularly from Yola North, Adamawa State.

Population growth exerts enrollment ratio and primary schools (Olanrewaju, 2011). This, by extension affects the quality of primary education. This problem situation suggests that there is need to plan for enrollment of pupil into primary school. Planning can be made possible if information with the future on the problem under consideration is provided.

Forecasting into the future using suitable forecasting techniques which include population projection is a means towards providing information into the future inform of expected population growth. In the light of this, we intends to carry out statistical investigation of population growth on primary school enrollment in Yola North L.G.A. of Adamawa State.

The aim of this paper is to investigate population growth and the trend of children enrollment in primary schools in Yola North Adamawa State from 2006 to 2021. The work will objectively examine the enrollment of school age children of age 6-11 years corresponding to primary school, analyze the pattern of enrollment according to sex and age, forecast the future enrollment of children into primary schools as population increases, and make recommendations based on the findings.

The study is significant in the sense that the policy makers will be able to address the cause of children not enrolling in primary schools to improve literacy level in the State. Also the projected schools enrollments will help the government in planning for the future schools and facilities.

\section{Assumption}

The population growth rate of the National Population Commission (NPC) was used to project the population of Yola North Adamawa State from 2006 to 2021. The rate of population growth is assumed constant.

\section{Population Projection}

Newell (1988) refers to projection as extending by hand a live of graph showing how total population changes over time. A "best-guess" Calculation of the number of people expected to be alive at a future data based on assumptions about population size, birth, death and migration. Population projections are useful for a number of reasons and help stake holders plan for near and distant future. If we know how many people are in a country or region, this puts us in a better position to assess the need for new jobs, teachers, schools, requirement for resources etc. Population projection can help us estimate future population size. Population projection are also important for raising awareness of issues among policy 
makers, for example a population projection can help illustrate the impact of increased population on school age population and school amenities provided.

\section{Reviewing Related Literatures}

Enrolment rates and years of schooling have risen in most countries of the world and this can be attributed to successive generations of parental investment in children's education within the confine of a stable household structure. Overtime, these investments have narrowed the differences in schooling across and within countries, and between and within genders.

In 1960, the average schooling of men aged 25 and over in advanced countries were 5.8 times that of men in developing countries. In 2000, this ratio fell to 2.4. During the same period, women's average schooling level as a ratio of men's increased from 0.5 to 0.7 in developing countries. In Nigeria, available evidence has shown that enrolment growth rates are quite insignificant and inconsistent. Specifically, the profile of primary education in Nigeria between 1980 and 2010 presents a gloomy picture as the growth in primary school enrolment has followed an inconsistent and haphazard pattern. The growth rate of primary school enrolment was 5.04 percent in 1983, when the enrolment figure was $15,308,384$ pupils, reduced to -10.64 percent in 1987 when enrolment was $11,540,178$ pupils and later increased to 7.47 percent in 1992. Highest growth rate was registered in 1996 with 14.31 percent followed by 1997 and2002 when it was both 10.00 percent and subsequently fell to -16.98 percent in 2004.it slightly increased to almost 13 percent in 2009 before later declining to 8.334 percent in 2010. It is however disheartening to observe that between 1980 and 2010, the growth rates of primary school enrolment is less than 15 percent. It should be noted that in spite of various policy interventions initiated by the government over the years to stimulate schooling at all levels of education, enrolment rates of school-aged children still remain abysmally poor. Hence, there is urgent need to investigate the various factors that are militating against primary school enrolment in Nigeria considering the crucial role it plays in the educational development of a child. Apart from this, there is ample documentary evidence on the impact of education; generally, on economic growth but the impact of primary enrolment is still very nascent (Babatunde, Olukayode 2013).

Over the last decade, Nigeria's exponential growth in population has put immense pressure on the country's resources and on already overstretched public services and infrastructure. With children less than 15 years of age accounting for about, 45 per cent of the country's population, the burden on education and other sectors has become overwhelming. Forty percent of Nigerian children aged 6-11 do not attend any primary school with the Northern region recording the lowest school attendance rate in the country, particularly for girls. Despite a significance increase in net enrolment rates in recent years, it is estimated that about 4.7 million children of primary school age are still not in school (UNICEF Global site Publication, 2015).

As such, the challenge is ensuring quality education and satisfactory learning achievements to fit the increased enrolment rates.

Population is the total number of men, women, boys, girls of different ages living in a defined location (for example a city, district, region or country) at a particular point in time (introduction to population projection).

Nigeria's population at Nigeria 2006 population census was 71, 709,859 males, 68,293,683 females and a total of 140,003,542, an increase of $63 \%$ from 1991 census, which indicate a significant growth in the country's population (Nigeria Masterweb, 2011).

Children comprise the majority of the population in many African countries and represent the region's future. If they lack the skills and knowledge needed to lead productive lives, Africa's economic development might be limited and its ability to reduce poverty jeopardized (World Bank, 2003).

Population growth at both national and sub-national levels represents a fundamental indicator for national decision makers, its insufficiency must be analyzed in relation to other factor affecting sustainability. However, rapid population growth can place strain on a country's capacity for handling a wide range of issues of economic social and environmental significance, particularly when rapid 
population growth occurs in conjunction with poverty and lack of access to resources or with sustainable pattern of production and consumption or in ecologically vulnerable zones (programme of Action International conference on population and Development (ICPD)).

According to Nigeria demographic and health survey (NDHS 2013), the estimated growth rate is $3.2 \%$

The benefit of education remains enormous and unquantifiable Education brings about sound knowledge, well informed habits, sound ideas, skills and enhancements of positives attitudes. It is therefore essential for it is skills regarded as an important bridge of social, economic and political mobility (Amutabli and Oketch, 2003). Record has it that, 189 counties so far have embraced the eight millennium development goals aimed at eradicating Poverty and improving the welfare of their people by 2015. Which implies that children all over the globe, boys and girls alike would be able to complete a full course of primary schooling (World Bank Review, 1995)

The National policy on education was enacted in 1977 and undergone three revisions, the most recent one in 2003 since1981, a number of decrees have been passed providing the legal frame work of education in the country. Like the decree No. 16 of 1985 places special emphasis on the education gifted and talented children within the National primary Education, also the No 96 of $1993 \mathrm{~b}$ re-established the National primary Education Commission (NPEC). It also provides the arrangement for funding primary education in the country. The most crucial strategy for sustainable education development in Nigeria is the Universal Basic Education (UBE) scheme, which was launched in 1990. In May 2004, the Nigeria legislature passed the UBE bill into law.

Of the primary age population (18.6 million children), $15.4 \%$ is not enrolled in school. The gross enrolment rate is estimated at about $70 \%$ and the national average for functional literacy is only $51 \%$. Furthermore, primary school enrolment growth rates-which average $4 \%$ annually-have not been able to fully clear the backlog and keep pace with the population growth rate, severe constraints both within and outside the education system have led to comparative lower completion rates - the current average being $6 \%$ for girls and 59\% for boys (Federal Ministry of Education, 2006). This means that every child irrespective of gender in Nigeria is expected by this Act to be enrolled in school particularly in Adamawa state where literacy rate of girls is very low.

Schools enrolment according to the United Nation (1970) refers to enrollment in any regular education during a well-define and recent time period. Instruction in particular skills which is not part of the recognized educational structure of the country (e.g. in service training courses in factories), is not considered 'school enrolment' for this purpose.

However, according to the data from 2006 school census, the country is said to have 87,941 primary schools. On enrolment figures from the schools, the document sated that there 13,302,269 or 54.5percent of male pupils while there were 11,302,269 or 45.5percent of female pupils in the primary schools than females in the North, about $65 \%$ of primary school children in the gender disparity indices showed $55 \%$ of the students were males and $45 \%$ females (Victor Sam, Punch new, 2009).

If one compare recent age-specific enrolment data collection from schools in age-specific population estimates produced by statistics department of South Africa (stat SA), it is easy to conclude that around 14 of the children who by law should be in school were not in school (Martin Gustafson 2012).

There are wide spread expansion of this educational level in all region of the world between 1999 and 2009. Globally, the gross enrolment ratio(GER) for lower secondary education increased from $72 \%$ to $80 \%$, the most notable increase incurred in sub-Sahara Africa, Where the GER for lower secondary education rose from $28 \%$ to $43 \%$ (Global Education Digest 2011). 
Adamawa is officially categorized as an educationally disadvantage State (EDS), meaning that it is characterized by low participation in education at all levels.

In national educational statistical returns the north east, along with the North West, often occupies the bottom ranks in the whole of Nigeria. The state population of more than 3 million is multi-ethnic, multilingual and multi-religions and the relatively low levels of literacy even in young people suggest that the practices of going to school and staying in school are not well embedded within society in general. For example, in Adamawa much of the population is engaged in agricultural work, often in subsistence farming and levels of poverty are high. There are also important trading routes and urban centers that contribute to the local economy (NPC and RTI International, 2011).

\section{Method Of Data Analysis}

The Sprague multipliers coefficient was applied in order to split the age, sex, and population of 2006 into single years so as to get school age population and project to 2021

The exponential growth model was used in projecting the population of Yola-North from 2006-2011, 2011-2016 and 2016- 2020.

\section{Enrollment Ratio}

This is the most commonly used indictor for accessing a state's enrollment at a particular level of education or of a particular age group. Thus, gross enrollment ratio of pupils in Yola North from 20062011-2016 and 2021 was computed by relating the total population of a particular level to the population that should be enrolled at that level.

This enables us to match the actual enrollment and school age population of $6-11$ years old.

$$
G E R=\frac{E_{p}^{t}}{N_{p}^{t}} \times 100
$$

Where

$$
\begin{aligned}
& \text { GER }=\text { Gross Enrollment ratio } \\
& E_{p}^{t}=\text { enrollment at primary level } \\
& N_{p}^{t}=\text { population of age group "a" which corresponds to primary level }(6-11) \text { in year t }
\end{aligned}
$$

\section{Population Growth Models}

Population growth models seek to represent the rate of growth in a population over a given period of time. There are many types of population growth models, but the exponential growth model will be used in this work. Common population growth models are: Geometric Growth Model, Malthusian Growth Model, Logistics Growth Model, Mechanistic Growth Model, and Exponential Growth Model

\section{Exponential Growth Model}

Continuous population growth in an unlimited environment can be modeled as exponential population growth. In the exponential growth model, population increase over time is a result of the number of individuals available to reproduce without regard to resources limits. In exponential growth, the population size increases at an exponential rate over time, continuing upward.

$$
\frac{D_{N}}{D_{t}}=r N
$$

That is to say, the change (D) in number of individuals (N) over a change (D) in time (t) equals the rate of increase or growth (r) in number of individuals (N) (Alecia M. Spooner, 2013). 
Exponential growth model is the appropriate model suitable for population projection with over lapping generations because it represents population growth as a continuous process.

Exponential growth model is given by:

$$
N_{t}=N_{0}+e^{r t}
$$

In this model $\mathbf{r}$ is a constant, $\mathbf{N}$ while is a variable. Therefore, as population increases or gets larger and larger the rate of increase depends on the constant $\mathbf{r}$ since it is multiplied by the population size $\mathbf{N}$. more so during exponential growth, the rate of population growth increases over time.

Naturally, population may grow at exponential rates for relatively short periods of time in the presence of birth rate and change in sex structure. Exponential growth model widely applied in estimating population growth with the following parameters.

$$
N_{t}=\text { population at time } \mathrm{t}, N_{0}=\text { initial population, e }=\text { Exponential, } \mathrm{r}=\text { Growth rate, } \mathrm{t}=\text { time interval }
$$

Here, exponential model was used to estimate population growth and school enrollment because it is the appropriate model suitable for population projection with overlapping generations since it represents population growth as a continuous process, and because data on live birth, death, and migration are not required in this work.

\section{Trend Analysis}

Trend analysis itself, is the practice of collecting information and attempting to spot a pattern, or trend in the information. It is basically used in predicting future outcome as well as estimating uncertain events in the past. This model can be used to describe behavior of the observed data. In particular, it may be useful to determine if measurements exhibit an increasing or decreasing trend which is statistically distinguished from random behavior. Trend is a long term change.

\section{Results And Discussion}

\section{Procedure:}

i. The exponential growth model was applied on the population figures of 2006 census figures, which was by age-sex structure, and same was used to obtain the population interval of five years i.e. the population of 2006 was projected using exponential growth model. 2011, 2016 and 2021.

ii. To project school age population, Sprague multipliers techniques were employed to break down five year age group to single year age group. The base population is advance each year by using projected survival to obtain population of pupils in Yola North L.G.A. This is a convenient method of determining school population. The population age group 6-11 years

In planning, the actual number of children aged 6, 7, 8, 9, 10 and 11 are required. Sprague's method which was used, is an interpolation method that has a table of coefficients, based on 5-years age group. 
Table 1: Yola North population (2006 Census)

\begin{tabular}{|l|l|l|l|}
\hline AGE GROUP & MALES & FEMALES & TOTAL \\
\hline $0-4$ & 14,697 & 14205 & 28,902 \\
\hline $5-9$ & 13,649 & 12242 & 25,891 \\
\hline $10-14$ & 12,183 & 11293 & 23,476 \\
\hline $15-19$ & 12,062 & 10570 & 22,632 \\
\hline $20-24$ & 12,747 & 10981 & 23,728 \\
\hline $25-29$ & 11,210 & 9231 & 20,441 \\
\hline $30-34$ & 7,756 & 6235 & 13,991 \\
\hline $35-39$ & 6,196 & 4954 & 11,150 \\
\hline $40-44$ & 5,086 & 3851 & 8,937 \\
\hline $45-49$ & 4,392 & 2449 & 6,841 \\
\hline $50-54$ & 3,065 & 1736 & 4,801 \\
\hline $55-59$ & 1,975 & 887 & 2,862 \\
\hline $60-64$ & 1,253 & 782 & 2,035 \\
\hline $65-69$ & 719 & 465 & 1,184 \\
\hline $70-74$ & 492 & 491 & 983 \\
\hline $75-79$ & 330 & 263 & 593 \\
\hline $80-84$ & 264 & 325 & 589 \\
\hline $85+$ & 303 & 335 & 638 \\
\hline TOTAL & $\mathbf{1 0 8 , 3 7 9}$ & $\mathbf{9 1 , 2 9 5}$ & $\mathbf{1 9 9 , 6 7 4}$ \\
\hline
\end{tabular}

Source: National Population Commission Yola 
Table 2: Projected Yola North Population for the year 2011

\begin{tabular}{|c|c|c|c|}
\hline Age group & $\begin{array}{ll}\text { Projection } & \text { for } \\
\text { Males } & \\
\end{array}$ & $\begin{array}{l}\text { Projection for } \\
\text { Females }\end{array}$ & $\begin{array}{l}\text { Projection total } \\
\text { for both sex }\end{array}$ \\
\hline $0-4$ & 17247 & 16670 & 33917 \\
\hline $5-9$ & 16017 & 14366 & 30383 \\
\hline $10-14$ & 14297 & 13252 & 27549 \\
\hline $15-19$ & 14155 & 12404 & 26559 \\
\hline $20-24$ & 14959 & 12886 & 27845 \\
\hline $25-29$ & 13155 & 10833 & 23988 \\
\hline $30-34$ & 9102 & 7317 & 16419 \\
\hline $35-39$ & 7271 & 5814 & 13085 \\
\hline $40-44$ & 5968 & 4519 & 10488 \\
\hline $45-49$ & 5154 & 2874 & 8028 \\
\hline $50-54$ & 3597 & 2037 & 5634 \\
\hline $55-59$ & 2318 & 1041 & 3359 \\
\hline $60-64$ & 1470 & 918 & 2388 \\
\hline $65-69$ & 844 & 546 & 1389 \\
\hline $70-74$ & 577 & 576 & 1154 \\
\hline $75-79$ & 387 & 309 & 696 \\
\hline 80-84 & 310 & 381 & 691 \\
\hline $85+$ & 356 & 393 & 749 \\
\hline TOTAL & 127,184 & 107,136 & 234,320 \\
\hline
\end{tabular}


Table3: Projected Yola North population for the year 2016

\begin{tabular}{|c|c|c|c|}
\hline Age group & $\begin{array}{l}\begin{array}{l}\text { Projection for } \\
\text { males }\end{array} \\
\end{array}$ & $\begin{array}{l}\text { Projection for } \\
\text { females }\end{array}$ & $\begin{array}{l}\text { Projection totals } \\
\text { for both sex }\end{array}$ \\
\hline $0-4$ & 20240 & 19562 & 39802 \\
\hline $5-9$ & 18796 & 16859 & 35655 \\
\hline $10-14$ & 16778 & 15552 & 32329 \\
\hline $15-19$ & 16611 & 14556 & 31167 \\
\hline $20-24$ & 17554 & 15122 & 32676 \\
\hline $25-29$ & 15438 & 12712 & 28150 \\
\hline $30-34$ & 10681 & 8586 & 19267 \\
\hline $35-39$ & 8533 & 6822 & 15355 \\
\hline $40-44$ & 7004 & 5303 & 12307 \\
\hline $45-49$ & 6048 & 3373 & 9421 \\
\hline $50-54$ & 4221 & 2391 & 6612 \\
\hline $55-59$ & 2720 & 1222 & 3941 \\
\hline $60-64$ & 1726 & 1077 & 2802 \\
\hline $65-69$ & 990 & 640 & 1631 \\
\hline $70-74$ & 678 & 676 & 1354 \\
\hline $75-79$ & 454 & 362 & 817 \\
\hline $80-84$ & 364 & 448 & 811 \\
\hline $85+$ & 417 & 461 & 879 \\
\hline TOTAL & 149,252 & 125,725 & 274,977 \\
\hline
\end{tabular}


Table 4: Projected Yola North Population for the year 2021

\begin{tabular}{|l|l|l|l|}
\hline Age group & $\begin{array}{l}\text { Projection for } \\
\text { males }\end{array}$ & $\begin{array}{l}\text { Projection for } \\
\text { females }\end{array}$ & $\begin{array}{l}\text { for both sex } \\
\text { FOR BOTH SEX }\end{array}$ \\
\hline $0-4$ & 23751 & 22956 & 46708 \\
\hline $5-9$ & 22058 & 19784 & 41842 \\
\hline $10-14$ & 19689 & 18250 & 37939 \\
\hline $15-19$ & 19493 & 17082 & 36575 \\
\hline $20-24$ & 20600 & 17746 & 38346 \\
\hline $25-29$ & 18116 & 14918 & 33034 \\
\hline $30-34$ & 12534 & 10076 & 22610 \\
\hline $35-39$ & 10013 & 8006 & 18019 \\
\hline $40-44$ & 8219 & 6224 & 14443 \\
\hline $45-49$ & 7098 & 3958 & 11056 \\
\hline $50-54$ & 4953 & 2806 & 7759 \\
\hline $55-59$ & 3192 & 1433 & 4625 \\
\hline $60-64$ & 2025 & 1264 & 3289 \\
\hline $65-69$ & 1162 & 751 & 1913 \\
\hline $70-74$ & 795 & 793 & 1589 \\
\hline $75-79$ & 533 & 425 & 958 \\
\hline $80-84$ & 427 & 525 & $\mathbf{3 2 2 , 6 8 8}$ \\
\hline $85+$ & 490 & $\mathbf{1 4 7 , 5 4 0}$ & \\
\hline TOTAL & $\mathbf{1 7 5 , 1 4 9}$ & & 952 \\
\hline
\end{tabular}

Table 5: Gross Enrolment Ratio (Male)

\begin{tabular}{|c|c|c|c|}
\hline Year & Enrolment & Population & GER \\
\hline 2006 & 10314 & 14689 & 70.21581 \\
\hline 2011 & 12104 & 17238 & 70.21696 \\
\hline 2016 & 14204 & 20229 & 70.2160 \\
\hline 2021 & 16669 & 23739 & 70.2178 \\
\hline
\end{tabular}

The result as presented in table 4.4 could be observed that from 2006 and 2011 Male GER was at high rate i.e.70.21581 \% and $70.21696 \%$ which implies that $29.78419 \%$ and $29.78304 \%$ are yet to be 
enrolled into primary school between 2006 and 2011. From these it's having been observed that there was a slight increase in population enrollment from 2006-2011. And at 2016 and 2021 the enrolment ratio is $70.2160 \%$ and $70.2178 \%$ Which implies that $29.784 \%$ and $29.7822 \%$ were yet to be enrolled? The enrolment ratio decrease from 2011-2016, and there was a slight increase as at 2021.

Table 6: Gross Enrolment Ratio (Females)

\begin{tabular}{|c|c|c|c|}
\hline Year & Enrolment & Population & GER \\
\hline 2006 & 9816 & 13258 & 74.03832 \\
\hline 2011 & 11519 & 15559 & 74.03432 \\
\hline 2016 & 13518 & 18259 & 74.0347 \\
\hline 2021 & 15864 & 21427 & 74.0374 \\
\hline
\end{tabular}

From table 4.5 it have been observed that from 2006 and 2011 the GER is $74.03832 \%$ and $74.03432 \%$ which implies that $25.96168 \%$ and $25.96568 \%$ were not enrolled in school, there is a slight decrease from 2006-2011. And 2016 and 2021 the GER of $74.03432 \%$ and $74.0347 \%$, it implies that $25.9653 \%$ and $25.9626 \%$ were not enrolled. From 2011-2016 there was decrease in the population enrolment ratio and from 2011-2016 there was increase in the enrolment ratio and from 2016-2021 there was increase. It implies that the enrolment ratio is increasing as the year passes by.

Table 7: Computation of school age population at primary level (6-11) for the year 2006

\begin{tabular}{|c|c|c|c|c|c|c|c|c|}
\hline \multirow{3}{*}{$\begin{array}{l}\text { Age } \\
\text { Group } \\
\text { AGE } 6 \\
\end{array}$} & \multicolumn{2}{|c|}{$\begin{array}{l}\text { Sprague's } \\
\text { Multipliers }\end{array}$} & \multicolumn{2}{|c|}{ Male Population } & \multicolumn{2}{|c|}{ Female Population } & \multicolumn{2}{|c|}{ School Age Popn } \\
\hline & & & & & & & \multirow{2}{*}{$\begin{array}{l}\text { Male } \\
3108.0896 \\
\end{array}$} & \multirow{2}{*}{$\begin{array}{l}\text { Female } \\
2785.9376 \\
\end{array}$} \\
\hline & 0.232 & $\begin{array}{l}- \\
0.0048 \\
\end{array}$ & 13649 & 12183 & 12242 & 11293 & & \\
\hline AGE 7 & 0.216 & -0.008 & 13649 & 12183 & 12242 & 11293 & 2850.72 & 2553.928 \\
\hline AGE 8 & 0.184 & -0.04 & 13649 & 12183 & 12242 & 11293 & 2024.096 & 1800.808 \\
\hline AGE 9 & 0.1408 & 0.0912 & 13649 & 12183 & 12242 & 11293 & 810.6896 & 693.752 \\
\hline AGE 10 & 0.0848 & 0.1504 & 13649 & 12183 & 12242 & 11293 & 2989.7584 & 2736.5888 \\
\hline AGE 11 & 0.0144 & 0.2224 & 13649 & 12183 & 12242 & 11293 & 2906.0448 & 2687.848 \\
\hline & & & & & & TOTAL & 14689.3984 & 13258.8624 \\
\hline
\end{tabular}


Table 8: Computation of school age population at primary level (6-11) years for 2011

\begin{tabular}{|c|c|c|c|c|c|c|c|c|}
\hline \multirow{3}{*}{$\begin{array}{l}\begin{array}{l}\text { Age } \\
\text { Group }\end{array} \\
\text { AGE } 6 \\
\end{array}$} & \multirow{2}{*}{\multicolumn{2}{|c|}{$\begin{array}{l}\text { Sprague's } \\
\text { Multipliers }\end{array}$}} & \multirow{2}{*}{\multicolumn{2}{|c|}{ Population Male }} & \multirow{2}{*}{\multicolumn{2}{|c|}{ Population Female }} & \multicolumn{2}{|c|}{ School Age Popn } \\
\hline & & & & & & & \multirow{2}{*}{$\begin{array}{l}\text { MALE } \\
3647.3184 \\
\end{array}$} & \multirow{2}{*}{$\begin{array}{l}\text { FEMALE } \\
3269.3024 \\
\end{array}$} \\
\hline & 0.232 & -0.0048 & 16017 & 14297 & 14366 & 13252 & & \\
\hline AGE 7 & 0.216 & -0.008 & 16017 & 14297 & 14366 & 13252 & 3345.296 & 2997.04 \\
\hline AGE 8 & 0.184 & -0.04 & 16017 & 14297 & 14366 & 13252 & 2375.248 & 2113.264 \\
\hline AGE 9 & $\begin{array}{l}0.140 \\
8\end{array}$ & -0.0912 & 16017 & 14297 & 14366 & 13252 & 951.3072 & 814.1504 \\
\hline AGE 10 & $\begin{array}{l}0.084 \\
8 \\
\end{array}$ & 0.1504 & 16017 & 14297 & 14366 & 13252 & 3508.5104 & 3211.3376 \\
\hline AGE 11 & $\begin{array}{l}0.014 \\
4\end{array}$ & 0.2224 & 16017 & 14297 & 14366 & 13252 & 3410.2976 & 3154.1152 \\
\hline & & & & & & TOTAL & $\begin{array}{l}17237.977 \\
6\end{array}$ & $\begin{array}{l}15559.209 \\
6\end{array}$ \\
\hline
\end{tabular}

Table 9: 2016 Computation of school age population at primary level (6-11) years for 2016

\begin{tabular}{|l|l|l|l|l|l|l|l|l|}
\hline \multirow{2}{*}{$\begin{array}{l}\text { Age } \\
\text { Group }\end{array}$} & \multicolumn{2}{l}{$\begin{array}{l}\text { Sprague's } \\
\text { Multipliers }\end{array}$} & \multicolumn{2}{l}{ Population Male } & \multicolumn{2}{l}{ Population Female } & \multicolumn{2}{l}{ School Age Popn } \\
\cline { 5 - 10 } & & & & & \multicolumn{2}{l}{ MALE } & FEMALE \\
\hline AGE 6 & 0.232 & -0.0048 & 18796 & 16778 & 16859 & 15552 & 4280.1376 & 3836.6384 \\
\hline AGE 7 & 0.216 & -0.008 & 18796 & 16778 & 16859 & 15552 & 3925.712 & 3517.128 \\
\hline AGE 8 & 0.184 & -0.04 & 18796 & 16778 & 16859 & 15552 & 2787.344 & 2479.976 \\
\hline AGE 9 & 0.1408 & -0.0912 & 18796 & 16778 & 16859 & 15552 & 1116.3232 & 955.4048 \\
\hline AGE 10 & 0.0848 & 0.1504 & 18796 & 16778 & 16859 & 15552 & 4117.312 & 3768.664 \\
\hline AGE 11 & 0.0144 & 0.2224 & 18796 & 16778 & 16859 & 15552 & 4002.0896 & 3701.5344 \\
\hline & & & & & & TOTAL & $\mathbf{2 0 2 2 8 . 9 1 8 4}$ & $\mathbf{1 8 2 5 9 . 3 4 5 6}$ \\
\hline
\end{tabular}


Table 10: Computation of school age population at primary level (6-11) years for the year 2021

\begin{tabular}{|c|c|c|c|c|c|c|c|c|}
\hline \multirow{3}{*}{$\begin{array}{l}\begin{array}{l}\text { Age } \\
\text { Group }\end{array} \\
\text { AGE } 6\end{array}$} & \multirow{2}{*}{\multicolumn{2}{|c|}{ Sprague's Multipliers }} & \multirow{2}{*}{\multicolumn{2}{|c|}{ Population Male }} & \multirow{2}{*}{\multicolumn{2}{|c|}{ Population Female }} & \multicolumn{2}{|c|}{ School Age Popn } \\
\hline & & & & & & & \multirow{2}{*}{$\begin{array}{l}\text { Male } \\
5022.9488 \\
\end{array}$} & \multirow{2}{*}{$\begin{array}{l}\text { Female } \\
4502.288\end{array}$} \\
\hline & 0.232 & -0.0048 & 22058 & 19689 & 19784 & 18250 & & \\
\hline AGE 7 & 0.216 & -0.008 & 22058 & 19689 & 19784 & 18250 & 4607.016 & 4127.344 \\
\hline AGE 8 & 0.184 & -0.04 & 22058 & 19689 & 19784 & 18250 & 3271.112 & 2910.256 \\
\hline AGE 9 & 0.1408 & -0.0912 & 22058 & 19689 & 19784 & 18250 & 1310.1296 & 1121.1872 \\
\hline AGE 10 & 0.0848 & 0.1504 & 22058 & 19689 & 19784 & 18250 & 4831.744 & 4422.4832 \\
\hline \multirow[t]{2}{*}{ AGE 11} & 0.0144 & 0.2224 & 22058 & 19689 & 19784 & 18250 & 4696.4688 & 4343.6896 \\
\hline & & & & & & TOTAL & 23739.4192 & 21427.248 \\
\hline
\end{tabular}

Table 11: Projected Enrolment (Males and Females)

\begin{tabular}{|l|l|l|l|l|}
\hline Year & 2006 & 2011 & 2016 & 2021 \\
\hline Male & 10314 & 12104 & 14204 & 16669 \\
\hline Female & 9816 & 11519 & 13518 & 15864 \\
\hline
\end{tabular}

Figure 1. Trend of Enrolment for Male Pupils

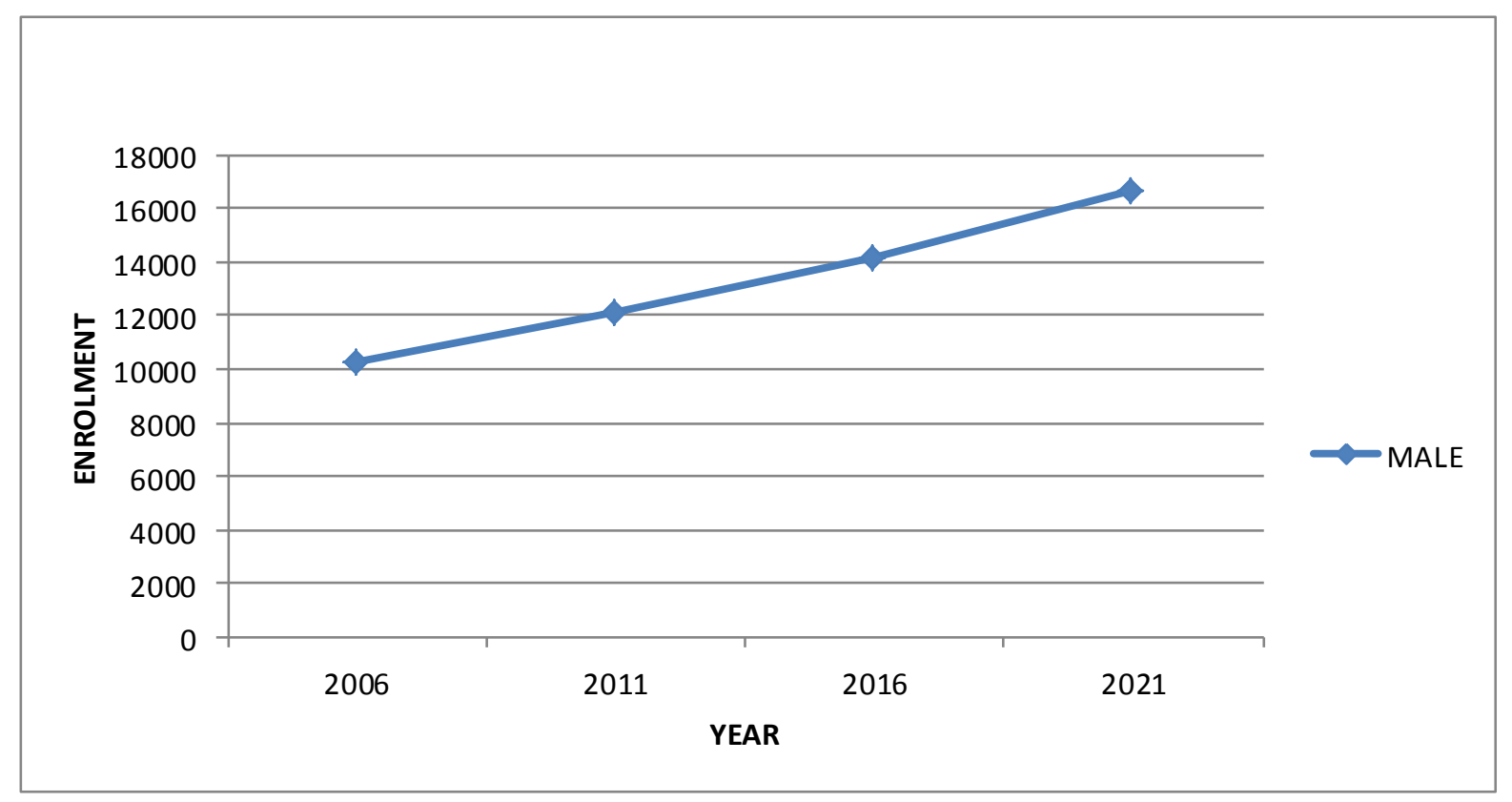




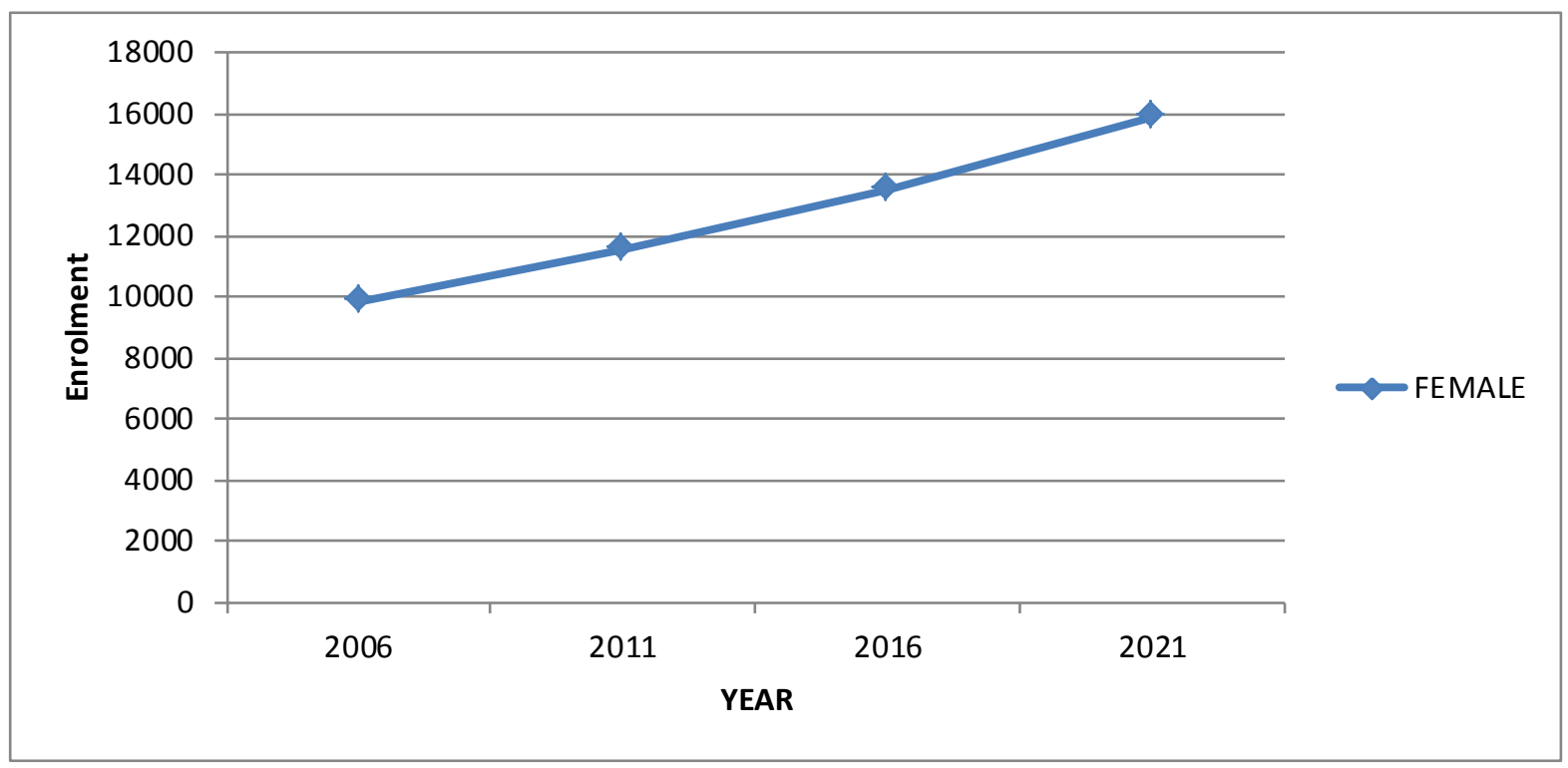

Figure 2. Trend Enrolment for Female Pupils

\section{Discussion of results and findings:}

Furthermore, it could be estimated that from table 1, 2, 3, and 4 the projected population of Yola north increases using 2006 as the base year which is 199674 to 234,320 in 2011, and 274,977 in 2016 to 322,688 in 2021. The population has also been broken down to age group and sex structure for clear analysis.

From table 7, 8, 9 and 10 the Sprague's multipliers coefficient table was used to split the enrolment into five years age group and into sex structure; from the result it has been observed that the enrolment of school age group increases each passing year with male's enrolment being higher than that of females. By the year 2021 the enrolment would increase by $0.001 \%$ which is not a very significant increase.

From the trend of enrolment in figure 1 and 2 the population enrolment of school age pupils corresponding to (6-11) years increases slightly, that means the level of enrolment is growing but at a very slow pace which means a lot more need to be done in order to encourage parents to send their children to school.

\section{Conclusion}

We have examined population growth side by side with the enrolment of school age pupils in Yola North Local Government Area of Adamawa State, Nigeria. It was observed that the enrolment rate was very slow as compared to the population growth.

\section{Reference}

[1] Adamawa State Universal Basic Education Board (ADSUBEB)

[2] Amutabi, M. N. and. Oketch, M.O. (2003). Experimenting in Distance; the African Virtual University (AVU) and the paradox of the World Bank in Kenya international journal of Education. 23(1), 57-73. Retrieved 10-10-2007.

[3] Babatunde O. (2014). Growth effects of primary enrolment in Nigeria: European Journal of Humanities and Social Sciences Vol. 29, No.1, 2014

[4] Babson N.O. (1998). Education and oral attainment, journal of higher education.

[5] Bianchi M. (1999). Time series analysis, a comparison of methods trend estimation. 
[6] Claeskens, G. and Hjort N. L. (2008). Model selection and Model Averaging, Cambridge University press.

[7] Derryberry S.K, and Peterson, T. (2014); model selection "Time series analysis and forecasting.

[8] Hollmann F.W. and Mulder T.J. (2000) Methodology and assumption for the population projection fo the united states. U.S Census bureau, population division, population projections branch.

[9] Imdullah M. (2014). Component of time series data; Time series analysis and forecasting.

[10] Library Fund, Inc. (2000), "Malthus, An essay on the principle of population: library of Economics" (description). Econlib.org webpage: Econlib - Malpop.

[11] Mundenge, J.S.G (1993). Keynote address on the role and function of African university in a rapidly changing ecomnomy. AAU newsletter . Accra.

[12] National Population Commission (NPC) Yola.

[13] Nigeria demographic and health survey, 1991. National population commission

[14] Onyeike V. and Ogujawa A.I (2000). An analysis evaluation of trend of primary school enrollment in Ebonyi state.

[15] Saints W.S (1992). Universities in African. The worldbank, Washington, D.C

[16] Sawyerr, A. (1994). The future Mission and roles of the African University. AAU Newsletter, Accra

[17] Thiam J. (1991). The mission of the African university in the threshold of the twenty first century. A paper prepared for the UNESCO/AAU seminar on planning management and governance of higher education in African university of Ghana Legon M. JournalsBank.com (2014). ISSN 2220-9425

[18] World Bank (1995). Development in practice Priorities and strategies for education USA. 